\title{
Land Use - Land Cover Change Analysis of Karur Town - A GIS Approach
}

\author{
S. Ravichandran*1, I. K. Manonmani*2 \\ ${ }^{*}$ Department of Geography, Madurai Kamaraj University, Madurai, Tamil Nadu, India \\ ${ }^{*}$ Department of Geography, Madurai Kamaraj University, Madurai, Tamil Nadu, India
}

\begin{abstract}
Article Info

Volume 8, Issue 3

Page Number : 360-366

\section{Publication Issue}

May-June-2021

\section{Article History}

Accepted : 20 May 2021

Published : 25 May 2021

Land use / Land cover change is one of the most sensitive factors that show the interactions between human activities and the ecological environment. This research study demonstrated the importance of geographical information system and remote sensing technologies in spatial temporal data analysis and also this paper shows a GIS and remote sensing approach for modeling of spatial - temporal pattern of land use and land cover change (LULC) in a fastest growing towns / industrial region of Karur town. QGIS 3.10 version and Arc GIS 10.2 software platforms were utilized in the study for Image processing, LULC mapping and change detection analysis. USGS Earth explorer Landsat series satellite imageries were acquired and LULC maps were prepared for the years 1991, 2000, 2010 and 2020. Supervised classification with maximum likelihood algorithm is adopted for LULC classification. The LULC classes are Built upland, Agricultural land, Barren land and Water body based on NRSA Level - I supervised classification. The Built-up area has drastically increased from 1991 to 2020. It has increased more than double. It was 17 percent in 1991 and increased to 40 percent in 2020. This clearly shows Karur town is the becoming more and more urbanized.
\end{abstract}

Keysords : LULC, GIS, Remote Sensing, ArcGIS 10.2, QGIS 3.10.

\section{INTRODUCTION}

Land is the basic natural resource for mankind for all his activities. Land use and land cover study is an important evidence for the study of urbanization. The term land use refers how people use the land for different purposes. The term land cover is the natural coverage of an area like water body, forest, grassland and barren land. The natural cover is changed by man according to his need and demand. Stamp (1948) has classified the needs of man into seven major categories viz., the need for work, home, food, transportation, communication, defence and recreation. Land use has been a concern primarily of social scientists, economists, geographers, anthropologists, planners and others. It is dynamic in nature and change from time in space. Change in land use/ land cover is due to the range of social, economic, political and cultural attributes of mankind. Land use/ land cover can be classified into rural and urban. Both 
the classifications have distinctive sub-classes. The change is rapid in urban areas and slow in rural areas. Carter (1974) indicates that the land use is basically dependent upon the functions of an urban area, which bring considerable variations in urban characters of various parts of the city.

There are number of models and theories developed in land use studies. Important among them are Von Thunen (1793-1850), Burges (1925), Hoyt (1939), Harries and Ullman (1945) and Dickinson (1951). According to Dickinson studies of cities in Western Europe, there is a common tendency of a city to grow in concentric zones of distinctive buildings and characters. His classification has three concentric morphological zones as follows

$\checkmark \quad$ the central fully built-up zone which is the core of the modern city,

$\checkmark \quad$ the compact and fully developed middle zone and

$\checkmark \quad$ the outer, partly built-up zone in which urban and rural areas are mixed

Western theories are not suitable to Indian towns. In the Indian context, Dickinson theory is partly agree with the transition from the core but not in concentric circle. Land use is influenced by economic, cultural, political, historical and land tenure factors at multiple scales, one the other hand, is one of the many biophysical attributes of the land that affect how ecosystems function (Turner et al., 1995). Understanding of land use changes is essential for sustainable management of natural resources and urban areas as it allows decision makers to take a broader view of urban system and its components. The increasing demands are contributing to significant transformations of land for a variety of land uses.

\subsection{LAND USE CLASSIFICATION ADOPTED IN THE PRESENT STUDY}

In this study, land use / land cover maps were prepared for 1991, 2000, 2010 and 2020 using Landsat data by Image Processing Method using ArcGIS 10.2 version, and QGIS 3.10 version. General land use/ land cover classes at level I, as classified by NRSA (1989), were delineated mainly to study the trend of urbanization for Karur town and its surrounding areas. The land use / land cover categories are water body, built-up area, agricultural land and barren land. Extent of built-up area in the last three decades gives an idea of as how Karur Town is expanding with direction of expansion. This trend of growth is compared with Survey of India topographic surveyed in 1968-69, first satellite image made available in 1972, and the subsequent imagery available for the years 1991, 2000, 2010 and 2020.

Mainly land use / land cover identified in Karur Town is

1. Built up area

2. Agricultural land

3. Barren land and

4. Water body

\section{STUDY AREA}

Karur municipality is situated at $10^{\circ} 55^{\prime} 0^{\prime \prime}$ to $10^{\circ} 57^{\prime} 30^{\prime \prime}$ North Latitudes and $78^{\circ} 2{ }^{\prime} 30^{\prime \prime}$ to $78^{\circ} 2{ }^{\prime} 70^{\prime \prime}$ East Longitudes. It is located in the district of the same name in the state of Tamil Nadu. According to 2011 census the total population of Karur Town is 214412 and the total area is 52.84 sq.km. The town has 48 wards (Fig 2.1). The town is situated on the banks of the river "Amaravathi".

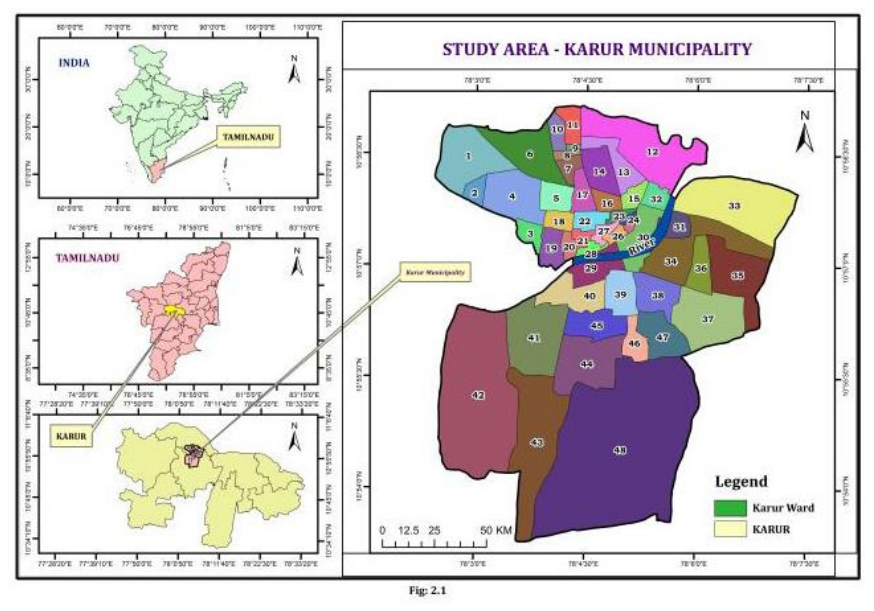




\subsection{PHYSICAL BACKGROUND}

Karur town is situated in Kongu Nadu plateau which is a part of Tamil Nadu. The entire area of the town is a Pedi plain. The Amaravathy River is a tributary of Kaveri River in Coimbatore district, Tamil Nadu. It is the continuation of the Pambar and Chinnar rivers in Kerala. The soils of Karur town can be broadly classified into 4 major soils types' viz., Red Soil, Thin Red Soil, Red Loam and River Alluvium Soil. The town enjoys a subtropical climate.

\subsection{DEMOGRAPHIC CHARACTERISTICS}

As per 2011 census, the total population of Karur town is 214412. It has an average population density is 41 persons per sq. $\mathrm{km}$. It has an average literacy rate is $79 \%$. It has an average sex ratio of 1011 females per 1000 males. On the whole, $94 \%$ of people come under the tertiary workers. All the wards have more concentration of tertiary workers. $3 \%$ of people were engaged the household industries. Only $3 \%$ of people were engaged cultivators and agricultural laborers.

\section{AIMS AND OBJECTIVES}

The aim of this study is to produce a LULC map of Karur town in order to detect the changes that have taken place over a given period of 1991, 2001, 2010 and 2020 using change detection method. The following specific objectives are pursued in order to achieve the aim.

$>$ To find out the existing LULC pattern of the period of 1991, 2001, 2010 and 2020.

$>$ To study about the change detection analysis for the period of $1991-2020$

\subsection{DATA COLLECTION}

The required datasets for the study are Urban Maps, Census Data and Satellite Imageries.

Primary Data: Satellite imageries of Landsat series over a time period are taken in the present study.
Landsat series satellite image data for the year 1991, 2001, 2010 and 2020 are downloaded. Secondary Data: Urban maps are collected from Town and country planning department in Karur town and census data collected from the 2011 census report.

\subsection{DETAILS OF SATELLITE IMAGERY USED FOR THE STUDY}

\section{Table 1}

Details of Satellite Imagery Used for The Study

\begin{tabular}{|c|c|c|c|c|c|}
\hline 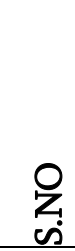 & 鼠 & 鼠 & 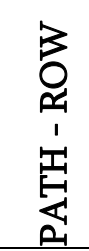 & 荇 & 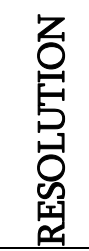 \\
\hline 1. & $\begin{array}{l}\text { Landsat } \\
8\end{array}$ & $\begin{array}{l}\text { OLI } \\
\text { TIRS }\end{array}$ & $\begin{array}{l}143- \\
52\end{array}$ & $\begin{array}{l}24^{\text {th }} \text { March } \\
2020\end{array}$ & $30 \mathrm{~m}$ \\
\hline 2. & $\begin{array}{l}\text { Landsat } \\
5\end{array}$ & ETM & $\begin{array}{l}143- \\
52\end{array}$ & $\begin{array}{l}9^{\text {th }} \text { February } \\
2010\end{array}$ & $30 \mathrm{~m}$ \\
\hline 3. & $\begin{array}{l}\text { Landsat } \\
5\end{array}$ & ETM & $\begin{array}{l}143- \\
52\end{array}$ & $\begin{array}{l}21^{\text {st }} \\
\text { December } \\
2000\end{array}$ & $30 \mathrm{~m}$ \\
\hline 4. & $\begin{array}{l}\text { Landsat } \\
5\end{array}$ & $\mathrm{TM}$ & $\begin{array}{l}143- \\
52\end{array}$ & $\begin{array}{ll}10^{\text {th }} & \text { April } \\
1991 & \end{array}$ & $30 \mathrm{~m}$ \\
\hline
\end{tabular}

\subsection{PREPARATION OF LAND USE LAND COVER MAPS}

Preparation of land use and land cover map of the study area is the second part of the methodology. This involves classification of study area into LULC using QGIS 3.10 and satellite data sets. It is the image handling software platform that permits users to processes geospatial imagery, vector data and other imageries. It is also used for LULC mapping, change detection analysis of the study area.

\section{RESULTS AND DISCUSSIONS}

The classification of land use land cover depends upon the study area and objective. Supervised classification is carried out using QGIS 3.10 platform in the present study. The study area is classified into 
Built up land, Agricultural land, Barren land and water body with an area of 52.84 sq.km. LULC maps were prepared for the year of 1991, 2001, 2010 and 2020 using the Landsat data set.

\subsection{LAND USE/LAND COVER IN 1991}

In 1991, the built-up area remained the same in the core area and had spread more along the National High way towards Tiruchirappalli in the east, Madurai in the south, north-west and north. Built up area has increased to $9.01 \mathrm{sq} . \mathrm{km}$ compared to 7.33 sq.km in 1980 with 17 percent. The area has slightly increased in a decade. Agricultural land has occupied 12.86 sq.km which is quarter of the total area of the Town. It is evenly distributed throughout the imagery except CBD area. It is reduced compared to 1980. Barren land is increased to 30.26 sq. $\mathrm{km}$ with 57 percent. More than half of the area is under the Barren land.

Table 2. Land use / Land cover 1991

\begin{tabular}{|c|c|c|c|}
\hline S.NO & LAND USE & $\begin{array}{l}1991 \\
\text { Area in sq.km }\end{array}$ & $\begin{array}{l}\text { Percentage } \\
\text { to the } \\
\text { Total Area }\end{array}$ \\
\hline 1 & Built up Land & 9.01 & 17 \\
\hline 2 & $\begin{array}{l}\text { Agricultural } \\
\text { Land }\end{array}$ & 12.86 & 24 \\
\hline 3 & Barren Land & 30.26 & 57 \\
\hline 4 & Water Body & 0.63 & 1 \\
\hline \multicolumn{2}{|l|}{ Total } & 52.84 & 100 \\
\hline
\end{tabular}

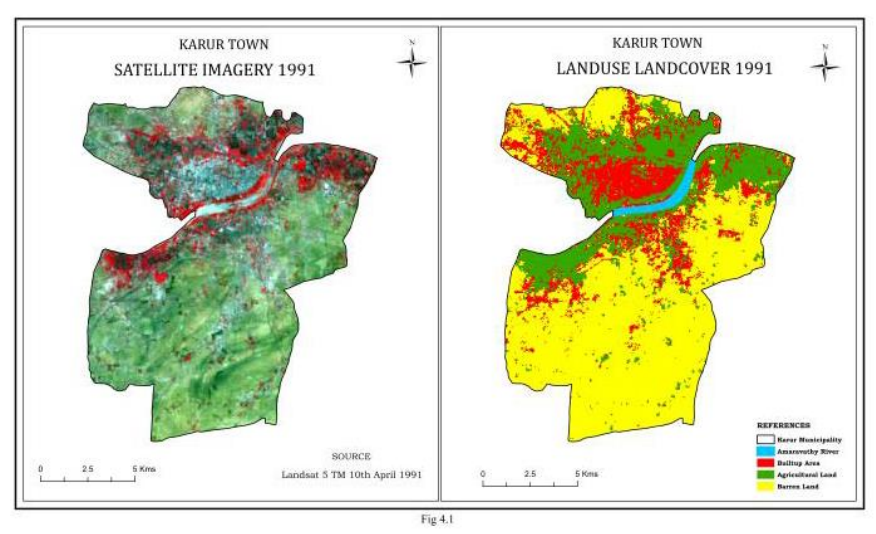

\subsection{LAND USE/LAND COVER IN 2000}

In 2000, land use in the Town has undergone many changes. The Built-up land has increased to 11.98 sq.km with 23 percent. It may be noted that population growth of this Town from Census of India supports this change. Area under Barren land decreased from 30.26 sq. $\mathrm{km}$ to 27.82 sq. km. Most of the Barren land in the Town is converted into Built up area. Agricultural land use has been reduced from 12.86 to 12.41 sq.km.

Table 3 - Land use / Land cover 2000

\begin{tabular}{|l|l|ll|l|}
\hline $\begin{array}{l}\text { S.N } \\
\text { O }\end{array}$ & LAND USE & $\begin{array}{l}2000 \\
\text { Sq.km Area in }\end{array}$ & $\begin{array}{l}\text { Percentag } \\
\text { e to the } \\
\text { Total Area }\end{array}$ \\
\hline 1 & $\begin{array}{l}\text { Built up } \\
\text { Land }\end{array}$ & 11.98 & 23 \\
\hline 2 & $\begin{array}{l}\text { Agricultura } \\
1 \text { Land }\end{array}$ & 12.41 & 23 \\
\hline 3 & $\begin{array}{l}\text { Barren } \\
\text { Land }\end{array}$ & 27.82 & 53 \\
\hline 4 & $\begin{array}{l}\text { Water } \\
\text { Body }\end{array}$ & 0.63 & 100 \\
\hline Total & 52.84 & \\
\hline
\end{tabular}

\subsection{LAND USE/LAND COVER IN 2010}

In 2010, Agricultural land is increased from 12.41 to 17.82 sq.km. It may be noted that agricultural lands were converted into barren land area. Built up land has slight increased from 11.98 to 12.56 sq. $\mathrm{km}$. Barren land is decreased from 27.82 sq.km to 21.83 sq.km. Here, Barren land is converted as Agricultural land use. 
Table 4 - Land use / Land cover 2010

\begin{tabular}{|l|l|l|l|}
\hline S.NO & LAND USE & $\begin{array}{l}\mathbf{2 0 1 0} \\
\text { Area in sq.km }\end{array}$ & $\begin{array}{l}\text { Percentage } \\
\text { to the } \\
\text { Total Area }\end{array}$ \\
\hline 1 & Built up Land & 12.56 & 24 \\
\hline 2 & $\begin{array}{l}\text { Agricultural } \\
\text { Land }\end{array}$ & 17.82 & 34 \\
\hline 3 & Barren Land & 21.83 & 41 \\
\hline 4 & Water Body & 0.63 & 1 \\
\hline Total & & $\mathbf{5 2 . 8 4}$ & 100 \\
\hline
\end{tabular}

\begin{tabular}{|c|c|c|c|c|} 
KARUR TOWN \\
SATELITE IMAGERY 2010 \\
KARUR TOWN
\end{tabular}

\subsection{LAND USE/LAND COVER IN 2020}

In 2020, Built up area has increased from 12.56 to 21.02 sq.km. Most of the built up areas are found in the southern parts of the town and along the High ways. Construction of bypass road from Trichi road to Namakkal road and from Dindigul to Namakkal or Salem road. Agricultural land is reduced from 17.82 to 10.09 sq.km. It is mainly noted that Agricultural land is coverted as builtup area. Barren lamd is 40 percent of the total area, the almost same as 2010.

Table 5. Land use / Land cover 2020

\begin{tabular}{|l|l|l|l|}
\hline $\begin{array}{l}\text { S.N } \\
\text { O }\end{array}$ & LAND USE & $\begin{array}{l}\text { 2020 Area in } \\
\text { sq.km }\end{array}$ & $\begin{array}{l}\text { Percentag } \\
\text { e to the } \\
\text { Total Area }\end{array}$ \\
\hline 1 & $\begin{array}{l}\text { Built up } \\
\text { Land }\end{array}$ & 21.02 & 40 \\
\hline 2 & $\begin{array}{l}\text { Agricultura } \\
\text { l Land }\end{array}$ & 10.09 & 19 \\
\hline 3 & $\begin{array}{l}\text { Barren } \\
\text { Land }\end{array}$ & 21.10 & 40 \\
\hline 4 & $\begin{array}{l}\text { Water } \\
\text { Body }\end{array}$ & 0.63 & 1 \\
\hline Total & & 52.84 & 100 \\
\hline
\end{tabular}

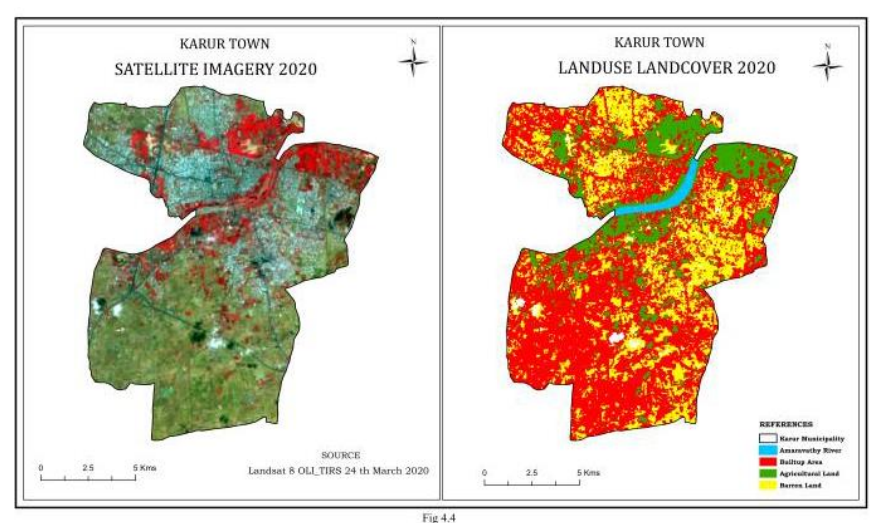

V. CHANGE OF LANDUSE LANDCOVER 1991, 2000, 2010 and 2020

Landuse is a dynamic. Landuse change in space and time. In the study landuse change considerd for the year 1991 to 2020 for four decades. The muncipality covers a total area of 52.84 sq.km. the change of landuse and landcover for the year 1991 to 2020 is given.

Table 6. Change of Land use and Landcover 1991 2020

\begin{tabular}{|c|c|c|c|c|c|c|c|c|c|}
\hline \multirow[b]{2}{*}{$\sum_{i}^{\circ}$} & \multirow{2}{*}{ 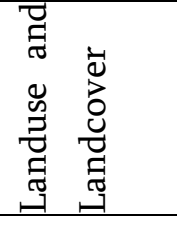 } & \multicolumn{2}{|c|}{1991} & \multicolumn{2}{|c|}{2000} & \multicolumn{2}{|c|}{2010} & \multicolumn{2}{|c|}{2020} \\
\hline & & $\begin{array}{l}. \Xi \\
\mathbb{J} \\
\stackrel{\Xi}{Z}\end{array}$ & 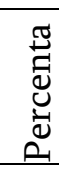 & $\begin{array}{l}. \Xi \\
\mathbb{J} \\
\stackrel{\mathbb{Z}}{Z}\end{array}$ & 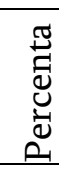 & $\begin{array}{l}. \Xi \\
\underset{Z}{\mathbb{Z}}\end{array}$ & 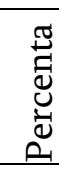 & $\begin{array}{l}. \Xi \\
\mathbb{J} \\
\dot{Z}\end{array}$ & 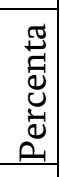 \\
\hline 1 & $\begin{array}{l}\text { Builtup } \\
\text { Land }\end{array}$ & $\begin{array}{l}9 . \\
01\end{array}$ & $\begin{array}{l}1 \\
7\end{array}$ & $\begin{array}{c}11 \\
.9 \\
8\end{array}$ & $\begin{array}{l}2 \\
3\end{array}$ & $\begin{array}{l}12 \\
.5 \\
6\end{array}$ & $\begin{array}{l}2 \\
4\end{array}$ & $\begin{array}{l}21 \\
.0 \\
2\end{array}$ & $\begin{array}{l}4 \\
0\end{array}$ \\
\hline 2 & $\begin{array}{l}\text { Agricultur } \\
\text { al Land }\end{array}$ & $\begin{array}{l}12 \\
.8 \\
6\end{array}$ & $\begin{array}{l}2 \\
4\end{array}$ & $\begin{array}{l}12 \\
.4 \\
1\end{array}$ & $\begin{array}{l}2 \\
3\end{array}$ & $\begin{array}{l}17 \\
.8 \\
2\end{array}$ & & $\begin{array}{l}10 \\
.0 \\
9\end{array}$ & \\
\hline 3 & $\begin{array}{l}\text { Barren } \\
\text { Land }\end{array}$ & $\begin{array}{l}30 \\
.2 \\
6\end{array}$ & $\begin{array}{l}5 \\
7\end{array}$ & $\begin{array}{l}27 \\
.8 \\
2\end{array}$ & $\begin{array}{l}5 \\
3\end{array}$ & $\begin{array}{l}21 \\
.8 \\
3\end{array}$ & $\begin{array}{l}4 \\
1\end{array}$ & $\begin{array}{l}21 \\
.1 \\
0\end{array}$ & 4 \\
\hline 4 & $\begin{array}{l}\text { Water } \\
\text { Body }\end{array}$ & $\begin{array}{l}0 . \\
63\end{array}$ & 1 & $\begin{array}{l}0 . \\
63\end{array}$ & 1 & $\begin{array}{l}0 . \\
63\end{array}$ & 1 & $\begin{array}{l}0 . \\
63\end{array}$ & 1 \\
\hline & $\begin{array}{l}1 \text { Area and } \\
\text { entage }\end{array}$ & $\begin{array}{l}52 \\
.8 \\
4\end{array}$ & $\begin{array}{l}1 \\
0 \\
0\end{array}$ & $\begin{array}{l}52 \\
.8 \\
4\end{array}$ & $\begin{array}{l}1 \\
0 \\
0\end{array}$ & $\begin{array}{l}52 \\
.8 \\
4\end{array}$ & $\begin{array}{l}1 \\
0 \\
0\end{array}$ & $\begin{array}{l}52 \\
.8 \\
4\end{array}$ & $\begin{array}{l}1 \\
0 \\
0\end{array}$ \\
\hline
\end{tabular}




\section{VI.CONCLUSION}

The Builtup area has drastically increased from 1991 to 2020. It has increased more than double. It was 17 percent in 1991 and increased to 40 percent in 2020. This might be due to increase in Textile industry, Busbuilding units and Allied industries. Apart from this many government office like Collectoarate, Court and SP office and many private institutions which has come up in the area. Due to this institutions settlement and roads have increased.

In 1991 percentage of Agricultural land was 25 percent and there was only one percent decrease in 2000. A large of Agricultural land was converted to non agricultural land in the year 2010 to 2020 . Nearely, 14 percent of the good agricultural land was converted in one decade (2010 to 2020). This shows that the Karur town is past growing.

The Barren land is also being converted for other purposes like settelement, industries and tranportation facilities. In the year 199158 percent of Barren land and decrese to 53 percnet in the year 2000. In the last four decades from 1991 to 2020 Barren land decreased by 18 percent. This clearly shows Karur town is the becoming more and more urbanised.

In the rencet times, the Karur town is expanding in the southern parts and along the High ways. Construction of bypass road from Trichi road to Namakkal road and from Dindigul to Namakkal or Salem road is fast developing.

\section{VII.REFERENCES}

[1]. Von Thunen. H (1826) The Isolated State.

[2]. Burges E.W (1925), The growth of the city: An Introduction to a research project in R.E Park and E.W Burgess Editors, The city, Chicago.

[3]. Hoyt (1939), The structure and growth of Residential neighbourhoods in American cities, Federal Housing Administration, Washington, D.C.
[4]. Ullman, E.L (1945), A theory of location for cities, American Journal of sociology, May 1945.

[5]. Stamp, L.D (1948), Land of Britain - its use and misuse London.

[6]. Dickinson R.E (1951), The west European city, London.

[7]. Carter (1974), The study of Urban Geography, Edward Arnold Press, London.

[8]. Turner, Roy (1995), India's urban future, Berkely university of California press.

[9]. Manonmani I.K (2010), "Spatio - Temporal Analysis of land use in Fringe area using GIS - A case study of Madurai city, TamilNadu". International Journal of Geomatics and Geosciences volume1, No.2

[10]. Dimitrios Triantakonstantis, Giorgos Mountrakis (2012), "Urban growth prediction: A Review of Computational models and Human's perceptions". Journal of Geographic Information System, 4, $555-587$.

[11]. Harshika A.Kaul and Ingle sopan (2012), "Land use and Land cover classification and change detection using high resolution temporal satellite data”. Journal of Environment, Vol.01, Issue 04, pp 146 - 152.

[12]. Praveen kumar Mallupattu and Jayarama Reddy sreenivasula Reddy (2013), “Analysis of Land use / Land cover changes using Remote sensing data and GIS at an urban area, Tirupati, India". The Scientific World Journal.

[13].Pandian.M, Rajagopal. N, Sakthivel.G and Amrutha.D.E (2014), "Land use and Land cover change detection using Remote sensing and GIS in parts of Coimbatore and Tiruppur districts, Tamilnadu - India". International Journal of Remote sensing and Geoscience.

[14]. Kuldeep pareta (2014), "Land use and Land cover change detection using multi temporal satellite data”. International Journal of management and social sciences Research volume 3, No.7.

[15]. Balaselvakumar.S, Sujatha.P, Ilanthirayan.A (2015), "Land use and Land cover change 
Detection in Lalgudi Block, Tiruchirapalli District - Using Remote Sensing and GIS Techniques". International Journal of Engineering Research and Applications, ISSN 2248 - 9622, Vol - 5, Issue 5, 2015, pp 108 - 117.

[16]. Vikram Agone (2015), "Change Detection of Land use / Land cover by using Remote Sensing and GIS”. Journal of Remote Sensing and Earth Sciences, Vol. 1, Issue 1, 2015, pp 15 - 20.

[17]. Vinod kumar H.A, Paresh Chandra Deka (2016), "Land use Land cover Analysis of sub water sheds in Belgaum using Remote sensing and GIS”. International Journal for Scientific Research and Development, ISSN 2321 - 0613, Vol.3, Issue 11, 2016, pp 147 - 152.

[18]. Irom Luckkychand meitai (2017), "Land use and Land cover analysis and dynamic modeling: A case study of Imphal East District, Manipur". International Journal of science and Research.

[19]. Vijayalaxmi mudhole, ViswanathAwati and Nataraj M (2018), "Land use / Land cover mapping and change detection analysis of Belagavi city, Karnataka”. International Research Journal of Engineering and Techonology Volume: 05 Issue: 07

[20]. Liping C, Yujun S and Saeed S (2018), "Monitoring and predicting land use and land cover changes using Remote sensing and GIS techniques - A case study of a hilly area, Jiangle China," PLOS one.

[21]. Vijayalaxmi mudhole, ViswanathAwati and Nataraj M (2018), "Land use / Land cover mapping and change detection analysis of Belagavi city, Karnataka”. International Research Journal of Engineering and Techonology Volume: 05 Issue: 07

[22]. Prabuddh Kumar Mishra, Aman Rai, Suresh Chand Rai (2019), "Land use and Land cover change detection using Geospatial techniques in the Sikkim, Himalaya , India”. The Egyptian Journal of Remote sensing and space Sciences.

\section{Cite this Article}

S. Ravichandran, I. K. Manonmani, "Land Use - Land Cover Change Analysis of Karur Town - A GIS Approach", International Journal of Scientific Research in Science and Technology (IJSRST), Online ISSN : 2395-602X, Print ISSN : 2395-6011, Volume 8 Issue 3, pp. 360-366, May-June 2021. Available at doi : https://doi.org/10.32628/IJSRST218373 Journal URL : https://ijsrst.com/IJSRST218373 